\title{
Is forest mushroom productivity driven by tree growth? Results from a thinning experiment
}

\author{
Simon Egli*, François Ayer, Martina Peter, Britta EILMAnN, Andreas Rigling
}

Swiss Federal Research Institute WSL, 8903 Birmensdorf, Switzerland

(Received 15 June 2009; accepted 17 September 2009)

Keywords:

wild forest mushrooms /

tree growth /

biodiversity /

forest management /

non-wood forest product

\begin{abstract}
- Most of the edible forest mushrooms are mycorrhizal and depend on carbohydrates produced by the associated trees. Fruiting patterns of these fungi are not yet fully understood since climatic factors alone do not completely explain mushroom occurrence.

- The objective of this study was to retrospectively find out if changing tree growth following an increment thinning has influenced the diversity patterns and productivity of associated forest mushrooms in the fungus reserve La Chanéaz, Switzerland.

- The results reveal a clear temporal relationship between the thinning, the growth reaction of trees and the reaction of the fungal community, especially for the ectomycorrhizal species. The tree-ring width of the formerly suppressed beech trees and the fruit body number increased after thinning, leading to a significantly positive correlation between fruit body numbers and tree-ring width.

- Fruit body production was influenced by previous annual tree growth, the best accordance was found between fruit body production and the tree-ring width two years previously.

- The results support the hypothesis that ectomycorrhizal fruit body production must be linked with the growth of the associated host trees. Moreover, the findings indicate the importance of including mycorrhizal fungi as important players when discussing a tree as a carbon source or sink.
\end{abstract}

Résumé - La productivité des champignons est-elle favorisée par la croissance des arbres ? Résultats d'une expérience d'éclaircie.

- La plupart des champignons comestibles des forêts sont mycorhiziens et dépendent des hydrates de carbone produits par les arbres associés. Le processus de fructification de ces champignons n'est pas encore totalement connu. À eux seuls, les facteurs climatiques ne sont pas en mesure d'expliquer l'apparition d'années pauvres ou riches en champignons.

- Cette étude a pour but de vérifier, d'une manière rétrospective, si la modification de la croissance des arbres, induite par une mise en lumière suite à une éclaircie, influence la diversité et la productivité des champignons dans la réserve mycologique de La Chanéaz en Suisse.

- Les résultats montrent une relation temporelle nette entre l'éclaircie, la réaction de croissance des arbres et la réaction des communautés de champignons, spécialement pour les espèces ectomycorhiziennes. Nous avons observé une augmentation tant de la largeur des cernes des hêtres autrefois dominés que du nombre de carpophores, conduisant à une corrélation positive entre les deux variables.

- La production de carpophores était influencée par la croissance annuelle précédente des arbres. La meilleure concordance a été trouvée entre la production de carpophores et la largeur des cernes deux ans auparavant.

- Les résultats sont en accord avec l'hypothèse que la production de carpophores des champignons mycorrhiziens est liée à la croissance des arbres associés. En outre, les résultats montrent qu'il est essentiel de tenir compte du rôle important des champignons mycorhiziens lorsqu'on débat de l'arbre en tant que source ou puits de carbone.

\footnotetext{
* Corresponding author: simon.egli@wsl.ch
} 


\section{INTRODUCTION}

In Switzerland, the existence of nearly 5000 macromycetes has been documented (Senn-Irlet et al., 2007). Among them, 1540 are mycorrhizal, living in a mutualistic symbiosis with forests trees and performing important functions within the forest ecosystem. They enhance the nutrient acquisition of their host trees, improve their tolerance of drought and their resistance to disease. In return, the autotrophic hosts provide photosynthetically fixed carbon to the heterotrophic fungal symbionts (Smith and Read, 1997). Most of the valuable edible forest mushrooms belong to this category of fungi, such as boletes (Boletaceae), chanterelles (Cantharellaceae), and truffles (Tuberaceae). Most mycorrhizal fungi are obligatorily biotrophic and only grow and fruit together with a living host tree. Their cultivation and fructification is not feasible on diverse substrates, unlike for such saprotrophic species as the Button mushroom (Agaricus bisporus) or the Oyster Mushroom (Pleurotus ostreatus) or Shiitake (Lentinus edodes). Although there have been some promising results with cultivating the golden chanterelle (Cantharellus cibarius) together with host plants (Danell and Comacho, 1997) and a few other edible mycorrhizal species (Yamada et al., 2001), these attempts are far from being commercially feasible. Understanding the mechanisms of fruit body production and finding ways of maintaining or even improving the yields of mycorrhizal forest mushrooms as a valuable non-wood forest product should therefore be welcomed by mushroom pickers and forest managers.

Temperature and water availability are key factors for the fruit body formation of forest mushrooms. It is a widespread experience of mushroom pickers that drought periods inhibit or delay fruit body formation. Such effects have also been demonstrated in irrigation (Wiklund et al., 1995) and drought experiments (Ogaya and Penuelas, 2005). It is common knowledge that good or poor mushroom years are determined by weather conditions, but climatic factors alone do not completely explain mushroom occurrence (Straatsmaa et al., 2001). Other factors must be also involved.

Mycorrhizal fungi mostly depend on photosynthetically fixed carbon produced by the associated host trees to extend their vegetative mycelium in the soil and to form mycorrhizas as well as fruit bodies for sexual reproduction. It has clearly been demonstrated that mycorrhizal fungi depend on current photosynthates for fruit body production and maintenance activities (Hacskaylo, 1965; Högberg et al., 2001; 2008). A reduction or an interruption of the carbohydrate flow from the host tree to the roots affect mycorrhizal colonization and fruit body production: the elimination of the photosynthetically active green part of the tree, e.g. by clear cutting, leads to an immediate disruption of ectomycorrhizal fruit body formation (Kropp and Albee, 1996; Ohenoja, 1988). Accordingly, tree girdling has been found to reduce fruit body production of ectomycorrhizal fungi virtually to zero (Högberg et al., 2001), and shading to reduce the fruit body production of Telephora terrestris (Hacskaylo, 1965) and Laccaria bicolor (Lamhamedi et al., 1994). Herbivores also reduce mycorrhizal colonization and alter the composition of the my- corrhizal fungal community as well (Gehring and Whitham, 2002). Moreover, defoliation experiments indicate that the number of fruit bodies of ectomycorrhizal fungi decreased to one third on defoliated trees compared to on control trees (Kuikka et al., 2003). Factors that influence tree growth and physiological processes such as photosynthetic activity and carbohydrate balance should also affect the associated ectomycorrhizal fungi. In this sense, forest management can therefore also be considered to influence ectomycorrhizal communities.

Thinning is intended to increase the dimensions and quality of trees as well as induce regeneration. The available results on the effects of thinning on the fungal community are inconsistent. Kropp and Albee (1996) and Buée et al. (2005) found that the fruit body production of some fungi were adversely affected by thinning while others were positively affected. A thinning of a 12-year-old Scots pine plantation had little effect on the ectomycorrhizal fruit body production (Shaw et al., 2003): out of 19 species tested only three (Suillus bovinus, Gomphidius roseus, and Cortinarius semisanguineus) significantly responded to the thinning and increased their fruit body production. Pilz et al. (2006) found that number and weight of chanterelles (Cantharellus formosus) produced significantly decreased after thinning in the first year, but no differences were observed during the following six years. Ayer et al. (2006) observed the highest species richness and fruit body abundance in medium dense Norway spruce stands compared to stands with both high and low densities. Ectomycorrhizal species produced twice as many fruit bodies in stands with medium density, whereas saprotrophic species did not differ significantly between the three densities. Ohenoja (1988) mentions two unpublished studies in Southern Finland and in Eastern Karelia, which both found higher fruit body yields in thinned forests compared to denser stands. In contrast, Luoma and colleagues (2004) showed that thinning caused a decline in fruit body production, but this effect varied greatly according to the season and to the pattern and level of thinning.

The aim of the present study was to find out if changing tree growth influences the diversity patterns and productivity of associated forest mushrooms in the fungus reserve $\mathrm{La}$ Chanéaz, where it was possible to study the effects of thinning the overstory in an old-growth forest. An experimental plot was thinned in winter 1986 as part of the normal silvicultural management plan of the local forest service ten years after the start of the mycological inventory. The inventory was continued for another $20 \mathrm{y}$. Four other study plots of the same size and inventoried in the same way as the thinned plot served as "non-thinned" controls. The tree-ring widths of the host trees were measured as the growth parameter.

We hypothesized that thinning and the resulting growth reactions of trees would influence the diversity and productivity of the associated mycorrhizal fungi.

\section{MATERIALS AND METHODS}

\subsection{Study site}

The study was carried out in the 75 ha fungus reserve "La Chanéaz" established in 1975 in south-western Switzerland. The reserve consists of several long-term observations plots and is located 
in a common forest type in the Swiss Central Plateau at $575 \mathrm{~m}$ a.s.1. The mixed old-growth forest contains deciduous and coniferous tree species of different ages (beech (Fagus sylvatica L.), oak (Quercus robur L.), spruce (Picea abies (L.) Karst.), fir (Abies alba Mill.), pine (Pinus silvestris L.), Eastern white pine (Pinus strobus L.), larch (Larix decidua Mill.)). This type of forest is popular for mushroom harvesting in Switzerland. The annual mean temperature is $8.5^{\circ} \mathrm{C}$ and the annual mean precipitation is $845 \mathrm{~mm}$ (norm values 1961-1990 from climate station Payerne, source: Meteo Schweiz). To prevent mushroom pickers and large forest animals having an inconvenient impact, the plots were enclosed by $2 \mathrm{~m}$ high fences.

Five $300 \mathrm{~m}^{2}$ observation plots $(30 \mathrm{~m} \times 10 \mathrm{~m}$ : plot 47, 51, 54, 58, 59) were installed within the reserve in 1977 . The forest structural characteristics of the 5 plots are given in Table I.

\subsection{Thinning}

In December 1986 an increment thinning was performed in one of the five plots (plot 59) in order to lighten the dense old-growth beech forest to favour the understory. This is a routine silvicultural intervention which was part of the forest management planning. From the 24 dominating trees of the overstory (11 larch, 6 beech, 3 Norway spruce, 2 eastern white pines, and 2 oaks), 11 trees were cleared (5 larch, 3 Norway spruce, 2 eastern white pines, and 1 oak).

\subsection{Measurement of tree-ring width}

Tree-ring width was measured to compare the growth before and after the intervention. Tree cores of 11 trees were taken in the thinned plot in spring 2007, consisting of 2 beech trees and 4 larch trees of the overstory and 5 beech trees from the former understory. As a control, tree cores were sampled in the four non-thinned plots from 10 overstory trees per plot of the dominating tree species. One core was taken from each tree at breast height $(1.3 \mathrm{~m})$ with an incremental borer. Tree-ring width was measured over the previous $30 \mathrm{y}$ using a linear table Lintab and the time series analysis and presentation programm (TSAP-Win) (Rinn, 2003). The individual tree-ring series were synchronised visually by crossdating and averaged to site chronologies.

\subsection{Fungal sampling}

In all plots fruit bodies of the epigeous mycorrhizal and saprotrophic macromycetes were identified and counted at weekly intervals from May to December (weeks 21-52). When first recorded, the fruit bodies were marked with methylene blue on the cap to avoid double counting in the subsequent week. The survey was started in 1977 and continued until 2006 (plots 51 and 54 only until 2005). Between 1980 and 1983 only the edible fungi were recorded. These four incomplete years were excluded from the analyses.

The mycorrhizal species were classified as "strictly beechspecific", "facultatively beech-specific" and "non beech-specific" (for the species classification see Appendix available online at www.afs. journal.org). This classification is not meant to be universally applicable, it strictly refers to the tree assemblage of the plot and the spatial distribution of the trees, i.e. a species is here called strictly beechspecific when there is no other potential tree species other than beech on the plot which could act as a symbiont, or when a potential tree is too far away from the fruit body to act as a potential host tree. The classification was based on the personal mycological experience of the authors and on literature sources (Arnolds et al., 1994; Holec, 1992; Kriegelsteiner, 1991; Moser, 1978).

\subsection{Data analysis}

Differences in species and fruit body numbers before (1977-1986) and after thinning (1987-2006) were examined by comparing the annual means of the two periods using a two-sample $t$-test. The analyses were performed with the statistical software R (R Development Core Team, 2007). To level out a general shift in mushroom productivity between the periods before and after thinning, the data from the thinned plot were adjusted by multiplying them by the mean quotient of the two periods of the four non-thinned plots (see Tab. II).

To analyse any relationship between the mean tree-ring chronology of beech and the number of fruit bodies on the thinned plot, Pearsons's correlations were calculated separately for each species category. In addition, the "Gleichläufigkeit" (GLK) between the mean tree-ring chronology and the number of fruit bodies was analysed. "Gleichläufigkeit" gives the similarity in curve progression between two time series. It is a measure of the year-to-year agreement between two chronologies, expressed as a percentage of cases of agreement (Schweingruber, 1983). Not only was GLK calculated for the data of the same year $(\mathrm{Lag}=0)$, but the time series were also shifted in relation to each other to study if the number of fruit bodies was also influenced by tree growth in previous years (Lag 1 to Lag 3).

\section{RESULTS}

In plot 59 mushroom production was very low in the period before thinning (1977-1986) and in the first three years after thinning (1987-1989). In 1990, the fourth year after thinning, species richness as well as fruit body numbers increased sharply (Fig. 1). Comparing the period before thinning (19771986) with the period after thinning (1987-2006), 4 times more species and 10 times more fruit bodies were counted on average per year (Tab. II). This increase was especially pronounced for the mycorrhizal species: they produced 5 times more species and 17 times more fruit bodies on average after the thinning. These values are based on the corrected data (see Materials and Methods), since in the non-thinned plots, species richness and number of fruit bodies were also two to three times higher in the 1987-2006 period than in the 19751986 period (Fig. 2 and Tab. II).

In the thinned plot 59 the mycorrhizal fungi clearly increased their dominance after the thinning relative to the nonmycorrhizal fungi from $44 \%$ to $63 \%$ of the total fruit body number (Tab. III). The most obvious was in the proportion of the strictly beech-specific mycorrhizal fungi after the thinning in plot 59. They accounted, on average, for $19 \%$ of the mycorrhizal fruit bodies before thinning, raising to $70 \%$ after thinning. The proportion of fruit bodies from the facultatively beech-specific fungi dropped from $70 \%$ to $15 \%$, while that of the non beech-specific remained unchanged.

The non thinned control plots $(47,51,54,58)$ were checked to see whether there was an analogous shift with the set of fungal species occurring in plot 59 between the two periods. The 


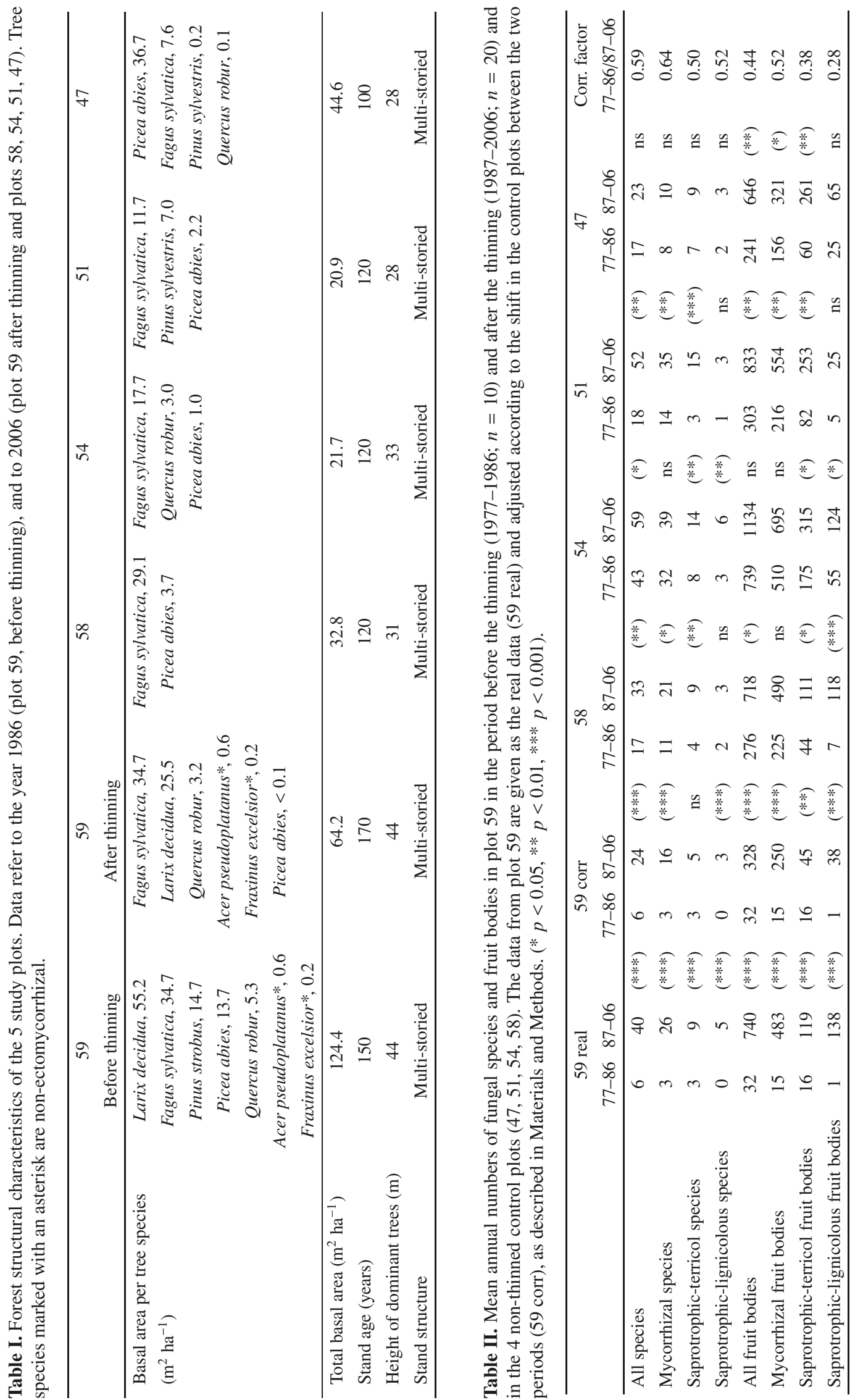



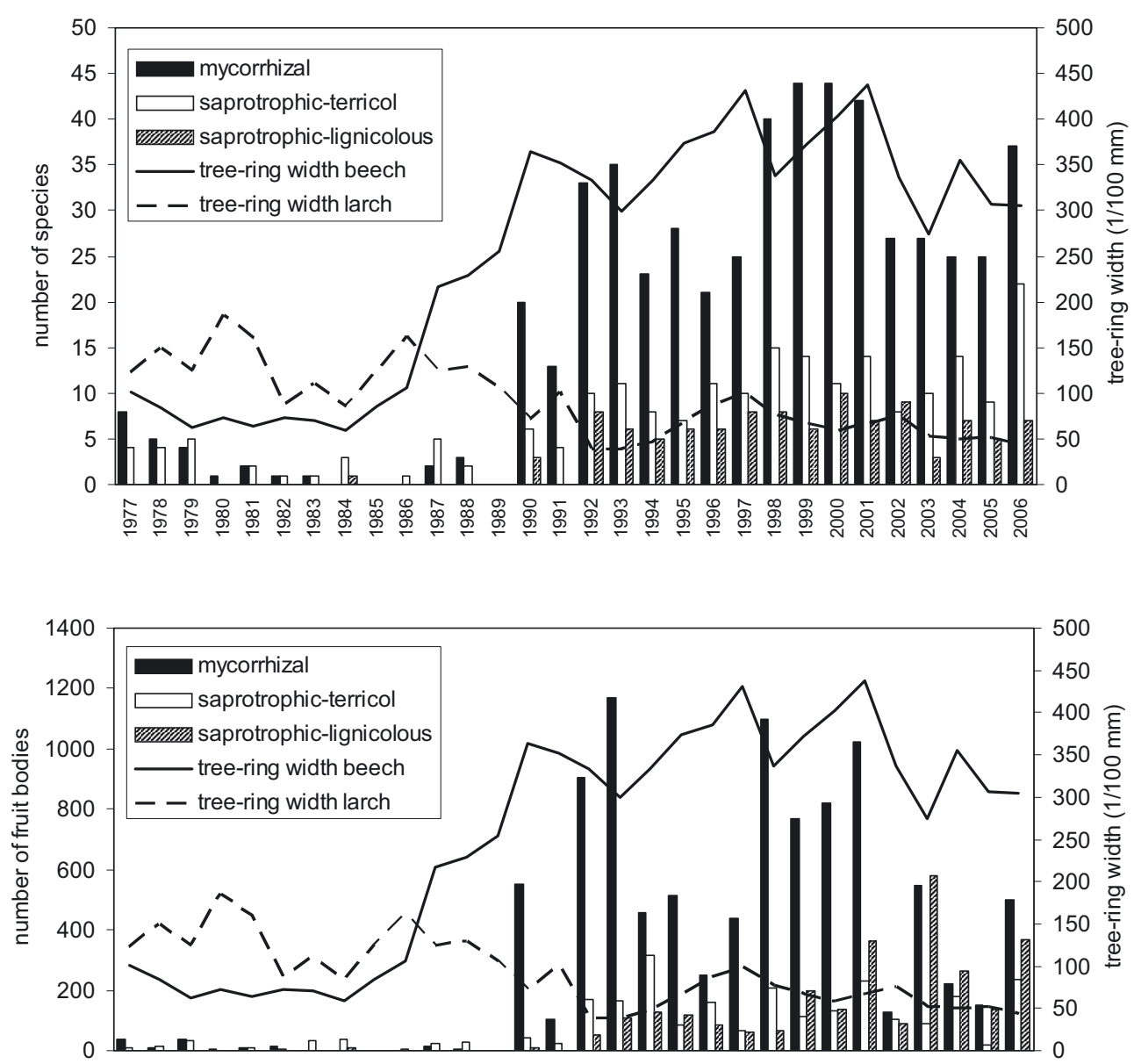

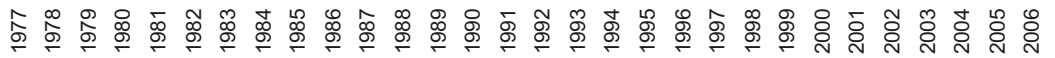

Figure 1. Fungal species and fruit body numbers from 1977 to 2006 in the thinned plot 59, and annual tree-ring width of beech (understory trees before thinning) and larch trees (overstory trees).

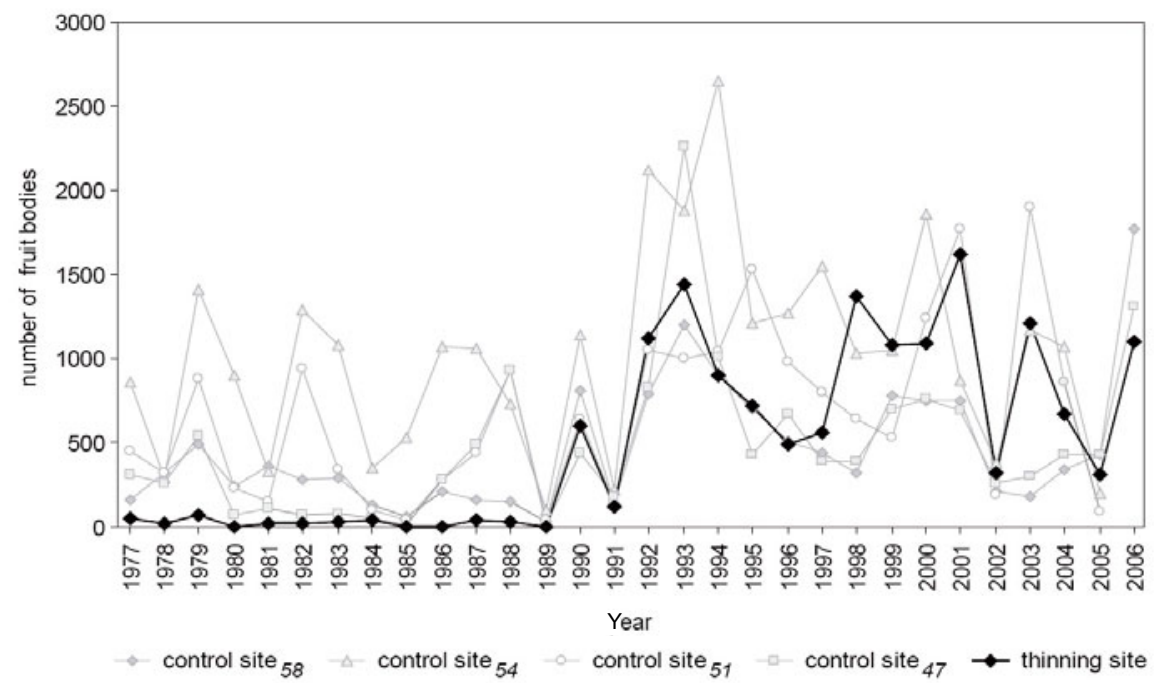

Figure 2. Fruit body numbers from 1977 to 2006 in all the plots. 
Table III. Shift in the relative fruit body abundance of mycorrhizal and non-mycorrhizal species and in the proportions per ecological category between the period before the thinning (1977-1986) and after the thinning (1987-2006) in plot 59 and in the non-thinned plots 47, 51, 54, 58. For this comparison only the species occurring in plot 59 were considered. 4 Increasing trend; $\triangleright$ decreasing trend.

\begin{tabular}{lccccc}
\hline & 59 & 58 & 54 & 51 & 47 \\
\hline Mycorrhizal & $44 \% \triangleleft 63 \%$ & $71 \% \triangleright 57 \%$ & $81 \% \triangleright 66 \%$ & $83 \% \triangleright 57 \%$ & $56 \% \triangleright 38 \%$ \\
Strictly beech-specific & $19 \% \triangleleft 70 \%$ & $68 \% \triangleright 52 \%$ & $78 \% \triangleleft 81 \%$ & $91 \% \triangleleft 92 \%$ & $25 \% \triangleright 21 \%$ \\
Facultatively beech-specific & $70 \% \triangleright 15 \%$ & $9 \% \triangleleft 27 \%$ & $8 \% \triangleleft 11 \%$ & $6 \% \triangleright 5 \%$ & $16 \% \triangleleft 38 \%$ \\
Non beech-specific & $11 \% \triangleleft 15 \%$ & $23 \% \triangleright 21 \%$ & $14 \% \triangleright 8 \%$ & $3 \% 3 \%$ & $59 \% \triangleright 41 \%$ \\
\hline Non mycorrhizal & $56 \% \triangleright 37 \%$ & $29 \% \triangleleft 43 \%$ & $19 \% \triangleleft 34 \%$ & $17 \% \triangleleft 43 \%$ & $44 \% \triangleleft 62 \%$ \\
Saprotrophic-terricol & $95 \% \triangleright 41 \%$ & $79 \% \triangleright 34 \%$ & $68 \% \triangleright 65 \%$ & $96 \% \triangleright 63 \%$ & $40 \% \triangleleft 47 \%$ \\
Saprotrophic lignicolous & $5 \% \triangleleft 48 \%$ & $10 \% \triangleleft 26 \%$ & $26 \% \triangleright 23 \%$ & $4 \% \triangleleft 36 \%$ & $21 \% \triangleright 12 \%$ \\
Parasitc, pathogenic & $0 \% \triangleleft 11 \%$ & $11 \% \triangleleft 40 \%$ & $6 \% \triangleleft 12 \%$ & $0 \% \triangleleft 1 \%$ & $39 \% \triangleleft 41 \%$ \\
\hline
\end{tabular}

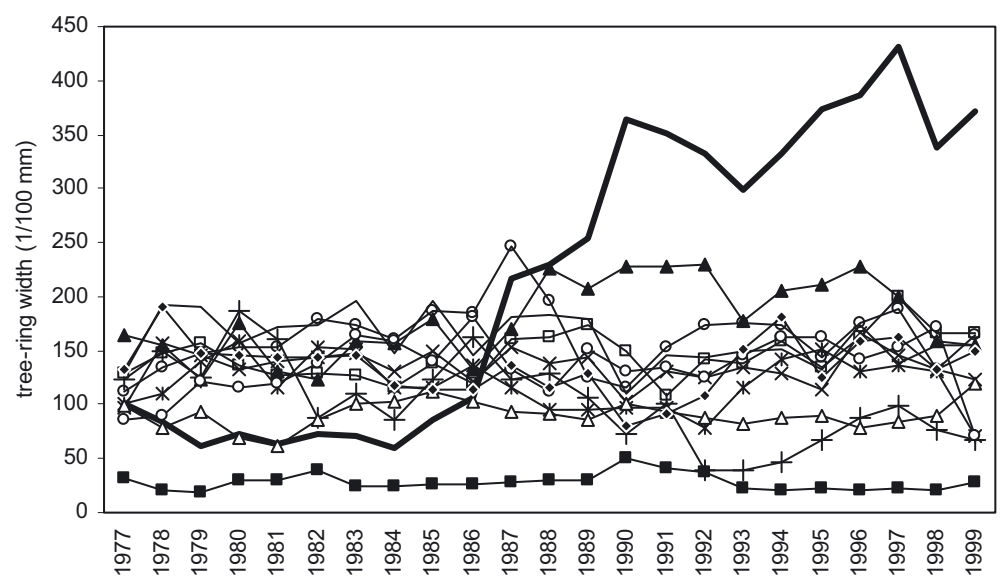

\begin{tabular}{|c|c|c|}
\hline 59 beech $(n=5, U)$ & $\neg 59$ beech $(n=2,0)$ & —-59 larch $(n=4,0)$ \\
\hline$\star 47$ spruce $(n=10,0)$ & $\rightarrow-51$ beech $(n=6,0)$ & $\rightarrow-51$ spruce $(n=2,0)$ \\
\hline$\rightarrow-51$ pine $(n=2,0)$ & $\multimap-54$ beech $(n=4,0)$ & $\neg-54$ oak $(\mathrm{n}=3, \mathrm{O})$ \\
\hline - 54 spruce $(n=3,0)$ & - -58 beech $(n=4,0)$ & -58 spruce $(n=6,0)$ \\
\hline
\end{tabular}

Figure 3. Annual tree-ring width from overstory (O) and understory (U) trees located in the thinned plot 59 and the 4 non-thinned plots 47 , 51 , 54, 58.

situation in these plots was rather different and the percentage of mycorrhizal fungi decreased relative to the non-mycorrhizal from the first to the second period. Furthermore, the proportion of fruit bodies of strictly beech-specific species did not differ between the two periods, and neither did those of the facultatively beech-specific and the non beech-specific species.

The tree-ring curves of the formerly suppressed beech trees showed an immediate reaction to the thinning, and tree-ring width increased in the season directly after the thinning intervention (Fig. 1). The tree-ring width of the formerly suppressed beech trees was on average 3 times higher after the thinning than beforehand. In contrast, the tree-ring widths of the remaining larch and beech trees of the overstory did not increase, and neither did those of the trees measured in the non-thinned plots (Fig. 3).

The strength of the positive correlation between fruit body numbers and tree-ring width of the formerly suppressed beech trees depended on the ecological category of the species, but was always positive (Fig. 4). Hence significantly more fruit bodies were found in years with wider tree rings than in years with narrow tree rings. The correlation coefficient varied between $0.45(p<0.05)$ for the facultatively beech-specific species and $0.67(p<0.001)$ for the strictly beech specific species. The "Gleichläufigkeit" GLK between the fruit body numbers and the tree-ring width of beech was between $43 \%$ and $52 \%$, and reached its maximum with a time lag of $2 \mathrm{y}$ (56\% to $63 \%)$.

Unexpectedly, the numbers of the fruit bodies of the nonmycorrhizal species was also found to correlate with tree-ring width with a time lag of $2 \mathrm{y}$ as well.

On the thinned plot, a total of 23 species was counted in the 1977-1986 period, compared to 173 in the 1987-2006 period. Over the whole period 176 species were detected in the thinned plot. Three species (Agaricus silvicola, Entoloma conferendum, Otidea onotica) only appeared in the first period, very infrequently. 96 of the 176 species are mycorrhizal, 52 of them are strictly beech-specific, the other 23 are facultative symbionts of beech, and 21 are non beech-specific. Many of the edible mushrooms occurred exclusively after the thinning: Boletus edulis, Xerocomus badius, and some Russula species, 


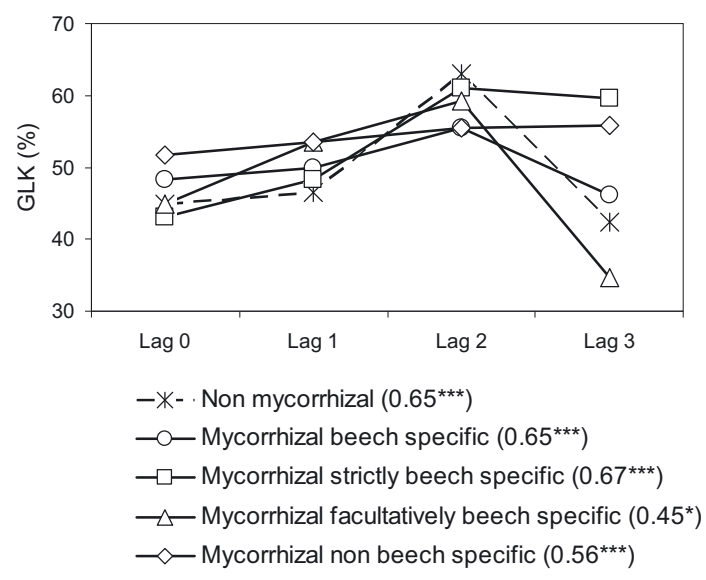

Figure 4. "Gleichläufigkeit" (GLK) between tree-ring width of beech trees in the thinned plot and fruit body numbers, with time shifts up to $3 \mathrm{y}$ between the tree-ring and fruit body data (Lag 0 to Lag 3; fruit body data shifted forward relative to tree-ring data). The number in brackets behind the mycorrhizal categories in the legend gives the correlation coefficient and the $p$-value between the number of fruit bodies and the tree-ring width of beech trees for Lag 0 . ( $* p<0.05$, $* * p<0.01, * * * p<0.001$.)

Craterellus cornucopioides, Amanita rubescens, Hypholoma capnoides. In contrast, in the control plots these species have been present since the beginning of the inventory, occurring with uniform frequency throughout the whole period. The one exception was Hypholoma capnoides, which was absent on these plots. Of the 3 species which were only present before thinning in plot 59, Otidea onotica was also only present in the first years on the other plots, but Agaricus silvicola and Entoloma conferendum were found troughout the whole period.

\section{DISCUSSION}

Our results reveal a clear temporal relationship between the thinning, the growth reaction of trees and the reaction of the associated fungal community. The most telling argument for a causal relationship between tree growth and mycorrhizal mushroom productivity is the clear shift of the mycorrhizal fruit body production towards beech-specific fungi from proportionally $19 \%$ prior to thinning to $70 \%$ afterwards. We interpret this change as a direct reaction to the change in the forest's structural characteristics from being a larch- to a beech-dominated forest. Before the thinning the suppressed beech trees in the shade of the old trees had low growth rates with an annual increment of $0.5-1.0 \mathrm{~mm}$. The thinning intervention altered this situation considerably. The formerly suppressed beech trees increased their growth dramatically, displaying annual increments between 3 to $4.5 \mathrm{~mm}$, whereas the few formerly dominating larch and beech trees continued their slow growth (0.5 to $2 \mathrm{~mm})$. This increase in tree-ring width might have been caused by the increase in crown irradiation of the formerly shaded beech trees, which then induced an increase of the photosynthetic activity.
In the three non-thinned plots in which beech was also the dominating tree species $(51,54,58)$, no tendency of a shift towards strictly beech-specific species was observed in the same time frame. We deduce that this shift was not a general phenomenon in our fungus reserve, but must be related to the growth reaction of the beech trees to the thinning.

The very poor fruit body production on the plot 59 prior to thinning can be explained by the high stand density and the extremely high tree basal area (Bonet et al., 2008), and according to the results of Hintikka (1988) by the high stand age (150 y).

Waring (1987) postulated a hierarchy for the carbon allocation in a tree. According to his theory, a tree invests its carbohydrates first in photosynthetic tissues (buds, new foliage) and in new roots. Additional carbohydrates go into storage reserves in the stem and the roots, and only then into diameter growth. That means that a tree producing a wide tree ring has already allocated reserves to the roots, which are then available for mycorrhizal fungi. The amount of carbon storage was probably reduced in the slow growing larch trees and in the suppressed beech trees, leading to less availability of carbohydrates for the mycorrhizal fungi. In contrast, after the thinning intervention the emerging beech trees probably generated a carbohydrate surplus which the mycorrhizal fungi could use. Kranabetter and Kroeger (2001) came to a similar conclusion in a partial cutting experiment in a coniferous forest in British Columbia. They hypothesized from their results and those of Last et al. (1979) that increased growth of residual trees might enhance mushroom fruiting through greater tree vigour and photosynthetic activity. This assumption is also supported by the results of Cranswick (1979), who found that the starch content increased substantially in twigs of formerly shaded trees when overstory trees were removed. Moreover, the biomass of ectomycorrhizal fruit bodies positively correlates with starch concentration in fine roots (Kuikka et al., 2003).

An interesting experiment in this context is described by Fortin et al. (2008), who used pine seedlings colonized by Laccaria bicolor in an in-vitro system under laboratory conditions. The system produced fruit bodies in lower or higher quantities according to the length of the photo period. They postulated that the starting point of the forest mushroom season coincides with the completion of growth of associated trees in the beginning of fall when the terminal buds are developed. At that moment, trees seem to change their carbon balance strategy and start to direct their photosynthesis products to the roots. This coincides with the finding of $\mathrm{Li}$ et al. (2002) that the mobile carbon pool in the roots in September is nearly twice that in May.

Our results and these findings support the hypothesis that ectomycorrhizal fruit body production might be coupled with the physiological status of the associated tree. In other words, strongly growing trees with a high photosynthetic capacity tend to produce more ectomycorrhizal fruit bodies than poorly growing trees, as already postulated by Pilz et al. (1998).

The fruit body production of non-mycorrhizal species also increased after the thinning treatment. This was not to the same extent as with the mycorrhizal ones, but the increase was also significant. Here the reaction cannot be explained directly as 
the result of the tree growth since these fungi are not physiologically dependent on living trees. There must be other factors with a similar time pattern. A possible explanation could be an accelerated decomposition of the organic matter as a side-effect of the thinning, since changes in the canopy structure result in altered lighting, soil moisture and temperature conditions (Ballard, 2000). Light is not a relevant factor for fungi, since they do not depend on light for growth. But the resulting changes in soil temperature and moisture regimes are probably more relevant for fungal growth. The saprotrophic species seem to react directly to these effects by increasing their litter- and humus-decomposing activity, whereas the mycorrhizal fungi react indirectly through the growth response of the associated trees. It is also conceivable that the increased tree growth generates a higher production of litter biomass, and this in turn favours the saprotrophic species. The fungal diversity and fruit body production of both the saprotrophic and the mycorrhizal species fluctuated at a high level for the $17 \mathrm{y}$ following the thinning, even though canopy began to close within a few years after the thinning intervention and reached a comparable level like before thinning. This indicates that other factors besides the microclimatic changes caused by the thinning must be primarily responsible for the shift in diversity and fruit body numbers.

While tree growth started in 1987 in the first season after thinning, fruit body production was delayed for $3 \mathrm{y}$ after the thinning intervention. 1987 and 1988 were productively very low mushroom years in the thinning plot, but not in the non thinned plots where production was average. A possible reason for this might be the temporary site disturbance caused by the intervention itself, which led to the soil being exposed to the sun and thus becoming much drier. In a thinning experiment described by Pilz et al. (2006), fruit body production of Cantharellus formosus decreased in the year after thinning probably also due to site disturbance, but recovered in the following years. The three-year delay in the reaction of the fruit bodies to the thinning does not exactly coincide with the 2-y time lag observed before fruit body production fits well with tree-ring width. This discrepancy might be due to the fact that 1989, the third year after the thinning, was a generally a very poor mushroom year with nearly no fruit body production in the whole region.

Fungal fruit body production reacts immediately to a reduction or an interruption of the carbohydrate flow to the roots (Högberg et al., 2001; Kropp and Albee, 1996), its reaction to the opposite process, an increase in carbohydrate availability, seems to be delayed. The time lag of two years might be due to the carbon consumption strategy of mycorrhizal fungi. They might first invest a surplus of carbohydrates into building-up the soil mycelium to fullfill their vital survival functions, and only secondarily in fruit body production for sexual reproduction.

\section{CONCLUSIONS}

We have found a clear temporal correspondence between thinning, the growth reaction of trees and the reaction of the associated fungal community. It was unfortunately not feasible to replicate the thinning treatment, because it was a routine silvicultural intervention within the forest management plan and repeating the experiment was not possible. Nevertheless, we still found strong indications of a causal relationship between tree growth and the productivity of mycorrhizal fungi. Most striking was the clear shift in the proportion of beech-specific fungi after thinning, which was absent in the control plots. More research would help to verify our findings, especially thinning experiments in other forest stands with trees of different age and species composition. It could also help to identify other variables involved in the fruit body formation and productivity of forest mushrooms. Our findings clearly show the necessity of including mycorrhizal fungi as important players in the carbon source/sink discussion of a tree. Furthermore, we recommend that forest managers should also consider the interplay between trees and forest mushrooms in management policy because edible mushrooms are interesting non-wood products of our forests whose yield may well be positively influenced by forest management.

Acknowledgements: We would like to thank the Forest Service of the Canton of Fribourg for their support and for allowing us to use the La Chanéaz site for this study. We are also grateful to Andreas Zingg for calculating the tree growth data and to Silvia Dingwall for her critical reading of the manuscript.

\section{REFERENCES}

Arnolds E., Opdam A., Van Steenis W., and De Fries B., 1994. Mycocoenology of stands of Fagus sylvatica L. in the northeastern Netherlands. Phytocoenologia 24: 507-530.

Ayer F., Zingg A., Peter M., and Egli S., 2006. Effets de la densité des tiges des pessières de substitution sur la diversité et la productivité des macromycètes d'une forêt du Plateau suisse. Rev. For. Fr. LVIII 5: $433-448$.

Ballard T.M., 2000. Impacts of forest management on northern forest soils. For. Ecol. Manage. 133: 37-42.

Bonet J.A., Pukkala T., Fischer C.R., Palahi M., de Aragon J.M., and Colinas C., 2008. Empirical models for predicting the production of wild mushrooms in Scots pine (Pinus sylvestris L.) forests in the Central Pyrenees. Ann. For. Sci. 65: 206.

Buée M., Maurice J.-P., Marçais B., Dupouey J.-L., Garbaye J., and le Tacon F., 2005. Effet des interventions sylvicoles sur les champignons sylvestres. Forêt-Entreprise 164: 26-32.

Cranswick A.M., 1979. Food reserves of Douglas fir trees defoliated by Lepidopterous larvae in Kaningaroa SF. Forest Research Institute Internal Report No. 13. Prod. For. Div. Rotorua, N.Z.

Danell E. and Camacho F.J., 1997. Successful cultivation of the golden chanterelle. Nature 385: 303.

Fortin J.A., Plenchette C., and Piché Y., 2008. Les mycorhizes, la nouvelle révolution verte. Édition Multimondes, Québec, Canada, 131 p.

Gehring C.A. and Whitham T.G., 2002. Mycorrhiza-Herbivore interactions: population and community consequences. In: van der Heijden M.G.A. and Sanders I. (Eds.), Mycorrhizal Ecology, Ecological Studies, Vol. 157, Springer Verlag, Berlin, pp. 295-316.

Hacskaylo E., 1965. Telephora terrestris and mycorrhizae of Virginia pine. For. Sci. 11: 401-404.

Hintikka V., 1988. On the macromycete flora in oligotrophic pine forests of different ages in South Finland. Acta Bot. Fenn. 136: 89-94. 
Högberg P., Nordgren A., Buchmann N., Taylor A.F.S., Ekblad A., Högberg M.N., Nyberg G., Ottosson-Löfvenius M., and Read D.J., 2001. Large-scale forest girdling shows that current photosynthesis drives soil repiration. Nature 411: 789-792.

Högberg P., Högberg M.N., Göttlicher S.G., Betson N.R., Keel S.G., Metcalfe D.B., Campbell C., Schindlbacher A., Hurry V., Lundmark T., Linder S., and Näsholm T., 2008. High temporal resolution tracing photosynthate carbon from the tree canopy to forest soil microorganisms. New Phytol. 177: 220-228.

Holec J., 1992. Ecology of macrofungi in the beech woods of the Sumava mountains and Sumava foothills. Ceska Mykologia 46: 163-198.

Kranabetter J.M. and Kroeger P., 2001. Ectomycorrhizal mushroom response to partial cutting in a western hemlock - western redcedar forest. Can. J. For. Res. 31: 978-987.

Krieglsteiner G.J., 1991.Verbreitungsatlas der Großpilze Deutschlands. Band 1, Ulmer, Stuttgart, 596 p.

Kropp B.R. and Albee S., 1996. The effects of sylvicultural treatments on occurence of mycorrhizal sporocarps in a Pinus contortea forest: a preliminary study. Biol. Conserv. 78: 313-318.

Kuikka K., Härmä E., Markkola A., Rautio P., Roitto M., Saikkonen K., Ahonen-Jonnarth U., Finlay R., and Tuomi J., 2003. Severe defoliation of Scots pine reduces reproductive investment by ectomycorrhizal symbionts. Ecology 84: 2051-2061.

Lamhamedi M.S., Godbout C., and Fortin J.A., 1994. Dependence of Laccaria bicolor basidiome development on current photosynthesis of Pinus strobes seedlings. Can. J. For. Res. 24: 1797-1804.

Last F.T., Pelham J., Mason P.A., and Ingleby K., 1979. Influence of leaves on sporophore production by fungi forming sheating mycorrhizas with Betula spp. Nature 280: 168-169.

Li M.H., Hoch G., and Körner C., 2002. Source/sink removal affects mobile carbohydrates in Pinus cembra at the Swiss treeline. Trees 16: 331-337.

Luoma D.L., Eberhart J., Molina R., and Amaranthus M.P., 2004. Response of ectomycorrhizal fungus sporocarp production to varying levels and patterns of green-tree retention. For. Ecol. Manage. 202: 337-354.

Moser M., 1978. Die Röhrlinge und Blätterpilze. Gustav Fischer Verlag, Stuttgart, $532 \mathrm{p}$.
Ogaya R. and Penuelas J., 2005. Decreased mushroom production in a holm oak forest in response to an experimental drought. Forestry 78 : 279-283.

Ohenoja E., 1988. Effect of forest management procedures on fungal fruit body production in Finland. Acta Bot. Fenn. 136: 81-84.

Pilz D., Molina R., and Liegel L., 1998. Biological productivity of chanterelle mushrooms in and near the Olympic Peninsula Biosphere Reserve. Ambio 9: 8-13.

Pilz D., Molina R., and Mayo J., 2006. Effect of thinning young forests on Chanterelle mushroom production. J. For. Ecol. 104: 9-14.

Rinn F., 2003. TSAP-Win, Time series analysis and presentation for dendrochronology and related application. User reference. Rinn Tech Heidelberg, p. 91.

R Development Core Team, 2007. R: a language and environment for statistical computing. R Foundation for Statistical Computing, Vienna, Austria. http://www.R-project.org.

Schweingruber F.H., 1983. Der Jahrring; Methodik, Zeit und Klima in der Dendrochronologie. Bern, Haupt Verlag, p. 234.

Senn-Irlet B., Bieri G., and Egli S., 2007. Rote Liste Grosspilze. Rote Liste der gefährdeten Arten der Schweiz. Umwelt-Vollzug Nr. 0718, Bundesamt für Umwelt, Bern und Eidgenössische Forschungsanstalt für Wald, Schnee und Landschaft WSL, Birmensdorf, p. 92.

Shaw P.J.A., Kibby G., and Mayes J., 2003. Effects of thinning treatment on an ectomycorrhizal succession under Scots pine. Mycol. Res. 107: $317-328$.

Smith S.E. and Read D.J., 1997. Mycorrhizal Symbiosis. Academic press, London, UK.

Straatsma G., Ayer F., and Egli S., 2001. Species richness, abundance, and phenology of fungal fruit bodies over 21 years in a Swiss forest plot. Mycol. Res. 105: 515-523.

Waring R.H., 1987. Characteristics of trees predisposed to die. Bioscience 37: $569-574$.

Wiklund K., Nilsson L.-O., and Jacobsson S., 1995. Effect of irrigation, fertilization, and artificial drought on basidioma production in a Norway spruce stand. Can. J. Bot. 73: 200-208.

Yamada A., Ogura T., and Ohmasa M., 2001. Cultivation of mushrooms of edile ectomycorrhizal fungi associated with Pinus densiflora in vitro mycorrhizal synthesis. Mycorrhiza 11: 59-66. 